Notes

\title{
Getting Women Work That Isn't \\ Women's Work: Challenging Gender \\ Biases in the Workplace Under Title VII
}

\author{
Maxine N. Eichner
}

Although title VII of the Civil Rights Act of $1964^{1}$ has prohibited discrimination in employment for almost a quarter of a century, the labor market remains overwhelmingly segregated by sex. Almost half of all employed women work in occupations that are at least eighty percent female, and over half of employed men work in occupations that are at least eighty percent male. ${ }^{2}$ This sex segregation limits women to fewer types of jobs, ${ }^{3}$ restricts their opportunities for career advance-

1. 42 U.S.C. $\$ \S 2000 \mathrm{e}-2000 \mathrm{e}-17$ (1982). Section 703(a)(1) makes it unlawful for an employer "to fail or refuse to hire or to discharge any individual, or otherwise to discriminate against any individual with respect to . . . compensation, terms, conditions, or privileges of employment because of ... sex." Section 703(a)(2) makes it unlawful for an employer "to limit, segregate, or classify his employees or applicants for employment in any way which would deprive or tend to deprive any individual of employment opportunities or otherwise adversely affect his status as an employee, because of ... sex." 42 U.S.C. $\$ 2000-e-2(a)$ (1982).

2. Women's Work, Men's Work: Sex Segregation on the Job 7, 23 (B. Reskin \& H. Hartmann eds. 1986) [hereinafter WOMEN's WORK, MEN's Work]; Rytina, Occupational Segregation and Earnings Differences by Sex, Monthly LAB. REv., Jan. 1981, at 49, 50 table 1.

3. Despite women's movement during the last decades into some sectors of the labor force traditionally occupied by men, the overwhelming majority of women remain in traditionally female occupations. In 1987, women represented $80 \%$ of all administrative support (including clerical) workers, but only $9 \%$ of all precision production, craft, and repair workers. WOMEN's BUREAU, OFFICE of THE SeCretaRY, U.S. Dep'T OF LABOR, LeAflet No. 88-2, FACTS ON WOMEN WORKERS 2 (1988) [hereinafter FACTS ON WOMEN WORKERS]. Moreover, in that year, women constituted only $6.4 \%$ of apprentices. $I d$. Overall, one quarter of all employed women work in three basic job categories-they type, sell retail goods, or prepare and serve food. Norwood, Perspectives on Comparable Worth: An Introduction to the Numbers, Monthly LaB. Rev., Dec. 1985, at 3, 4. 
ment, ${ }^{4}$ and ensures that they receive considerably less pay than men. ${ }^{5}$

Attempts to rid the work place of intentional discrimination have allowed women to make considerable progress toward equality, yet women's current confinement to the "pink collar" sphere of the labor market does not result solely from intentional discrimination by employers. Instead, job descriptions and structures that have been adapted to male incumbents continue to bar women from those sectors of the labor market from which they were once historically excluded by intentional discrimination. ${ }^{\circ}$ Demands of physical strength beyond that which most women possess, scheduling that conforms to typically male life patterns, job descriptions calling for stereotypically masculine traits, and myriad other requirements modeled on male characteristics perpetuate women's exclusion from tradi-

4. For example, in a study of eleven industries employing approximately $17 \%$ of the United States work force (motor vehicles and parts, steel, communications, retail stores, commercial banking, insurance carriers, and hotels and motels), a consulting group found that women, who accounted for $46 \%$ of nonsupervisory workers, represented $64 \%$ of those workers in jobs with the fewest opportunities for advancement. In stark contrast, women accounted for only $5 \%$ of those holding jobs with the most opportunities for advancement. WOMEN's WORK, MEN's WORK, supra note 2, at 237-38 (citing W. Grunker, D. CoOke \& A. Kirsch, Glimbing the Job Ladder: A Study of Employee AdVANCEMENT IN EleVEN INDUSTRIES (1970)).

5. Women continue to earn only 65 cents for every dollar earned by men when both work year round, full time. FACTS ON WOMEN WORKERS, supra note 3, at 3. In 1986, women with four years of college education had a median income below that of men with high school diplomas- $\$ 22,412$ and $\$ 24,701$ respectively. Id. The poverty rate of all persons in families maintained by women with no husband present was $34.2 \%$ in 1986 . Id. at 2 .

Approximately $35-40 \%$ of the discrepancy between men's and women's salaries can be traced to the fact that "female" jobs pay considerably less than do "male" jobs. WOMEN, WORK, AND WAGES: Equal Pay for Jobs of Equal Value 33, 321 (D. Treiman \& H. Hartmann eds. 1981) [hereinafter WOMEN, WORK, AND WAGEs]. The remainder of the differential between women's and men's salaries stems from men earning more than women within the same occupation. WOMEN's Work, MEN's WORK, supra note 2, at 10 (citing WOMEN, WORK, AND WAGES, supra). Preliminary data from the 1980 census suggests that there may have been a "slight increase in the effect of segregation [on earnings] between 1970 and 1979." Id.

6. Women's exclusion from the work force dates back to the early 19th century, when production moved from the home to the workplace as a result of industrialization. N. COTT, THE BONDS OF WomanHood 63-74 (1977). For the next century and a half, women were openly discriminated against by private employers, many of whom explicitly refused to hire women; even those who did hire women refused to hire married women or women with young children. A. KESSLER-HARRIS, Out to Work: A History OF WAge-EARning WOMEN IN THE UNITEd States 234-35, 254-59, 296-97 (1982). Women's second class status in the labor market was reinforced by state regulations that restricted the hours women could work and the occupations they could perform. See id. 180-214; WOMEN's WORK, MEN's WoRk, supra note 2, at 45 . The federal judiciary encouraged exclusionary policies against women. For example, in the now-infamous case of Bradwell v. Illinois, 83 U.S. (16 Wall.) 130, 141-42 (1872), the Supreme Court upheld women's exclusion from the Illinois bar. According to Justice Bradley's concurrence, in which two other members of the Court joined:

The natural and proper timidity and delicacy which belongs to the female sex unfits it for many occupations of civil life. The constitution of the family organization, which is founded in the divine ordinance, as well as in the nature of things, indicates the domestic sphere as that which properly belongs to the domain and functions of womanhood.

Id. at 141. In Muller v. Oregon, 208 U.S. 412 (1908), justifying state laws that restricted the hours women could work, the Supreme Court stated that "woman's physical structure and the performance of maternal functions place her at a disadvantage in the struggle for subsistence." Id. at 421 . Both the formal and informal restrictions on the entrance of women into traditionally male jobs kept the levels of sex segregation by occupation constant for the last century. WOMEN's WORk, MEN's WoRk, supra note 2 , at 1 . It was not until the passage of title VII that overt discrimination against women in the workplace was finally declared unlawful. Id. at 45 . 
tionally male jobs. These employment standards assume men to be the norm and relegate women who diverge from this norm to second class status in the labor market. ${ }^{7}$ If sexual equality is to be achieved, women's exclusion from traditionally male jobs must be recognized for what it isnot the natural product of women's differences from men, but the product of the social (de)valuation of women that isolates these differences and thereby ensures that women remain economically subordinated. As a growing literature of feminist jurisprudence argues, achieving sexual equality requires recognition that standards that disadvantage women are neither necessary nor unbiased, but are, in fact, discriminatory in a society composed of both men and women. ${ }^{8}$

7. Employers may also develop job descriptions and structures that make them inappropriate for men. See, e.g., Diaz v. Pan Am. World Airways, 442 F.2d 385 (5th Gir.) (airline argued, unsuccessfully, that duties of flight attendant justified restricting position to women), cert. denied, 404 U.S. 950 (1971). Principles developed in this Note can readily be applied to jobs from which men are excluded.

8. Debating such issues as pregnancy leave over the last decade, the feminist movement has split regarding how best to achieve sex equality. Advocates of the "equal treatment" position argue that women should strive for sex-neutral standards that deemphasize differences between the sexes; according to these advocates, women will be more successful in moving towards equality if simply allowed to compete against men under facially neutral standards. See, e.g., Williams, The Equality Crisis: Some Reflections on Culture, Courts, and Feminism, 7 Women's RTs. L. ReP. 175 (1982); Williams, Equality's Riddle: Pregnancy and the Equal Treatment/Special Treatment Debate, 13 N.Y.U. Rev. L. \& Soc. Change 325 (1985) [hereinafter Equality's Riddle]. They would therefore support a law requiring pregnancy leave only when it is part of a disability leave program available to both sexes.

"Special treatment" proponents, on the other hand, believe that the equal treatment position inadequately protects women when they differ from men. See, e.g., Krieger \& Cooney, The Miller-Wohl Controversy: Equal Treatment, Positive Action and the Meaning of Women's Equality, 13 GoldEN GATE U.L. REv. 513, 537-57 (1983); Scales, Towards a Feminist Jurisprudence, 56 IND. L.J. 375, 426-30 (1981). Rather than treating women equally only when they are situated similarly to men, "special treatment" advocates would support gender-specific classifications that benefit women when there are real differences between the sexes. They would thus accept a law requiring a pregnancy leave policy even where no general disability policy exists for workers of both sexes. See Krieger \& Cooney, supra; Scales, supra. In turn, equal treatment proponents criticize this approach for promoting the age-old sterotypical image of women as needing "special" protection. See Williams, Equality's Riddle, supra, at 371 .

An emerging group of feminists has begun to express dissatisfaction with the limited terms of this debate, however. Attention to whether women are treated similarly or differently under existing standards, they argue, ignores the real problem: the legitimacy of standards constructed on the basis of a male norm. In Catharine MacKinnon's words:

There is a politics to [framing the equality debate in terms of whether women should be treated the same as or different from men]. Under the sameness standard, women are measured according to our correspondence with man, our equality judged by our proximity to his measure. Under the difference standard, we are measured according to our lack of correspondence with him, our womanhood judged by our distance from his measure. Gender neutrality is thus simply the male standard, and the special protection rule is simply the female standard, but do not be deceived: masculinity, or maleness, is the referent for both.

C. Mackinnon, Difference and Dominance: On Sex Discrimination, in Feminism Unmodified: Discourses on Life and LAw 32, 34 (1987) [hereinafter Feminism Unmodified]. Sex equality efforts, these scholars contend, should move beyond a focus on similarity and difference to challenge the male-biased standards themselves and the social valuation of sexual difference. See, e.g., G. Mackinnon, Sexual Harassment of Working Women 101-41 (1979); Finley, Transcending Equality Theory: A Way Out of the Maternity and the Workplace Debate, 86 Colum. L. REv. 1118, 1143-63, 1168 (1986); Scales, The Emergence of Feminist Jurisprudence: An Essay, 95 YALE L.J. $1373,1374-76,1393-99$ (1986). This Note is predicated on that view. Sexual equality, it posits, concerns neither women's similarities with, nor their differences from, men. Instead, it concerns the relative power and social status of the sexes. In this view, women's similarities or differences from men are relevant only insofar as they are used as vehicles to perpetuate hierarchy. As Catharine 
Despite title VII's commitment to equality in the workplace, courts have not used either of its two frameworks of analysis, disparate treatment or disparate impact, to confront entrenched conceptions of job performance that exclude women. ${ }^{\circ}$ Disparate treatment doctrine, which prohibits practices motivated by discriminatory intent, is inherently unsuited to the task of identifying these biases because it guarantees similar treatment only for the similarly situated. Women, when they cannot or will not conform to male patterns of behavior, remain outside the scope of its protection. Disparate impact doctrine, which prohibits employment practices that have a discriminatory effect, could in theory challenge entrenched assumptions regarding job performance. This method of analysis has the potential to isolate and eliminate biased practices that exclude women. Yet in practice, courts have limited its effectiveness by wrongly accepting entrenched biases as essential to the job's performance and therefore as exempt from title VII's ban on practices that exclude women. ${ }^{10}$

This Note argues that title VII's ban on sex discrimination in employment compels courts to alter radically judicial analysis of challenges to jobs from which women are excluded in order to eliminate "male-biased" job standards. Part I of this Note argues that pervasive perceptions that jobs must be performed according to standards unnecessarily biased toward men deny women traditionally male jobs on the basis of their real and perceived differences from men. It suggests that these entrenched conceptions of job performance do not derive from requirements integral to

MacKinnon describes her revision of sex discrimination analysis, which moves away from issues of similarity and difference:

[t]he only question for litigation is whether the policy or practice in question integrally contributes to the maintenance of an underclass or a deprived position because of gender status. The disadvantage which constitutes the injury of discrimination is not the failure to be treated "without regard to" one's sex. . . . The unfairness lies in being deprived because of being a woman or a man, a deprivation given meaning in the social context of the dominance or preference of one sex over the other.

C. MacKinnon, Sexual Harassment of Working Women 117-18 (1979). Even scholars who support positions within the equal treatment/special treatment debate have agreed that eradicating malebiased standards is necessary to the achievement of equality. See, e.g., Taub \& Williams, Will Equality Require More Than Assimilation, Accommodation, or Separation from the Existing Social Structure?, 37 RuTGERS L. REv. 825 (1985).

9. The Supreme Court distinguished title VII's two causes of action in International Bhd. of Teamsters v. United States, 431 U.S. 324 (1977). According to the court, a "disparate treatment" claim is actionable when

[t]he employer simply treats some people less favorably than others because of their race, color, religion, sex, or national origin. Proof of discriminatory motive is critical, although it can in some situations be inferred from the mere fact of differences in treatment. . . .

Glaims of disparate treatment may be distinguished from claims that stress "disparate impact." The latter involve employment practices that are facially neutral in their treatment of different groups but that in fact fall more harshly on one group than another and cannot be justified by business necessity. Proof of discriminatory motive, we have held, is not required under a disparate-impact theory.

Id. at 335 n.15 (citation omitted).

10. The Supreme Court exempts practices demonstrated to be "business necessities" from its prohibition on practices that have a disparate impact on protected groups. Griggs v. Duke Power Co., 401 U.S. 424,431 (1971). 
jobs themselves, but instead reflect the gender of current job holders; women's historical exclusion from the labor market thereby causes and perpetuates these biases. Part II argues that courts refuse to challenge male-biased requirements because they tacitly accept these job standards as necessary and normal. Part III proposes a reformulation of disparate impact doctrine that challenges entrenched assumptions about job structures that are based on the image of the male worker.

\section{Male Biases in the Labor Market: Job Requirements That Disadvantage Women}

Many jobs in today's labor market require traits and life patterns generally associated with men. Although such job demands typically are perceived as necessary for optimal job performance, often they are unconnected to the actual needs of the job itself. Instead, these requirements are based on the faulty supposition that the job must be performed as it has always been performed by past employees. This assumption severely disadvantages women; because of women's historical exclusion from large sectors of the labor market, past employees of well-paying positions in our society are almost exclusively male. These beliefs about job performance may involve "mischaracterizing" the job (insofar as employers wrongly perceive that the job requires "masculine" traits) $)^{11}$ or "misstructuring" the job (insofar as employers unnecessarily construct the job in ways that do, in fact, make it more appropriate for men).

Large numbers of traditionally male jobs in our society are mis-

11. The general population continues strongly to associate particular personality characteristics with each of the sexes. J. Williams \& D. Best, Measuring Sex Stereotypes: A ThirtyNation Study (1982); Broverman, Vogel, Broverman, Clarkson \& Rosencrantz, Sex Role Stereotypes, A Current Appraisal, $28 \mathrm{~J}$. Soc. Issues 59 (1972) [hereinafter Broverman]. There is little consensus regarding how accurately the association of traits with the sexes reflects real, culturally conditioned differences between the sexes. Compare, e.g., E. MAccoBY \& C. JACKLIN, The PsyCHOL.OGY OF SEX DIFFERENCES (1975) (summarizing studies finding greater visual-spatial and mathematical abilities and more aggressive behavior among boys and greater verbal ability among girls) with C. Tavris \& C. Wade, The Longest War: SeX Differences in Perspective 40-73 (1984) (questioning findings of Maccoby and Jacklin). It is clear, however, that many such attributes are not integral to the nature of men and women, as the attributes that different societies assign to the sexes vary considerably. C. Epstein, Woman's Place: Options and Limits in Professional Careers 21 (1970).

This Note takes no position on the extent to which the cultural assignment of traits mirrors "real" personality differences between the sexes. Whether or not men and women are "really" different, the perception of difference is genuine and may profoundly affect the behavior of actors within the labor market. See S. Cohn, The Process of Occupational Sex-Typing 14 (1985); V. Oppenheimer, The Female Labor Force in the United States: Demographic and Economic Factors Governing Its Growth and Changing Composition 102-03 (1970). To the extent that differences between the sexes or the perceptions of these differences exist and are malleable, however, the proposal made here would help bridge the gap between the sexes in two ways. First, by placing women in positions traditionally held by men, it would enable women to develop and use traits typically associated with men. Second, by necessitating that "female" qualities be given their rightful place in the labor market, it would prompt men to develop and express these traits in order to succeed in the work world. 
characterized as requiring traits predominantly associated with men). ${ }^{12}$ As sociologists have long recognized, however, sex-typed traits commonly associated with a job often have little inherent connection with performance; instead, the perception that a job requires masculine traits typically derives from associating the job with its incumbents. ${ }^{13}$ For example, physicians in this country have traditionally been male, and good doctors have long been thought to exhibit traits associated with men, including detachment and rationality. In the Soviet Union, however, where seventy-five percent of physicians are women, medicine has long been considered an occupation requiring such qualities as nurturing and caring. ${ }^{14}$ Similarly, before the Civil War, the position of primary schoolteacher was seen as an intellectually grueling "male" occupation for which women lacked the requisite mental stamina. When the shortage of men during the Civil War necessitated the recruitment of female teachers, however, women moved into the profession, and schoolteaching was soon considered a nurturing activity which demanded a mothering presence. ${ }^{15}$

In addition to their association with male stereotypes, jobs also possess structures adapted overwhelmingly to the lifestyles and characteristics of

12. For example, qualities associated with men, such as coolness, detachment, and objectivity, are frequently associated with such occupations as engineering and architecture. Similarly, teaching, nursing, and social work are considered "female" occupations involving tasks judged to be expressive, nurturing, and person-oriented. C. EPstein, supra note 11, at 155; see also Massengill \& DiMarco, Sex Role Stereotypes and Requisite Management Characteristics: A Current Replication, 5 SEx Roles 561 (1979) (attributes assigned to the successful manager differ from those assigned to women); Miller, Gender Stereotyping and Perceptions of Occupational Success, in WOMEN AND Work: Selected Papers 1985 (M. Knezek, M. Barrett \& C. Collins eds. 1985).

Cynthia Miller documented the extent to which subjects stereotyped jobs both directly (by believing them more appropriately held by men or women) and indirectly (by attaching characteristics to them perceived to be either masculine or feminine rather than believing them appropriately limited to men or women per se). Id. She found that of 40 job categories chosen semi-randomly, "being male" was considered more important than "being female" for 13 occupations including police officer, postman, firefighter, salesman, and businessman. "Being female" was considered more important for 5 occupations: day care worker, secretary, maid, seamstress, and nurse. More interestingly, of the 21 occupations that subjects designated as sex-neutral, i.e., those which they did not believe were more appropriately held by either men or women on the basis of gender per se, subjects attributed more characteristics that they considered masculine to 16 positions. These occupations included: cameraman, lawyer, psychology professor, meteorologist, news reporter, small business operator, doctor, letter carrier, banker, mayor, salesperson, chairman of the board, and company spokesman. Subjects attributed higher numbers of "female" characteristics to only two occupations: hairdresser and interior decorator. The other three occupations were designated neutral with respect to characteristics perceived of as male or female. Id. at 73.

13. See S. Cohn, supra note 11, at 4; C. EPSTEIN, supra note 11, at 152; V. OPpenheimer, supra note 11, at 102-07 (identifying phenomenon of "job labeling," which perpetuates identification of a job with the sex of its incumbents); WOMEN's Work, MEN's WoRk, supra note 2, at 43-44.

14. C. EPSTEIN, supra note 11, at 154. The cross-societal variation in the sexual division of labor is large. For example, dentistry, a profession occupied primarily by women in Denmark, Poland, and the Soviet Union, is $93 \%$ male in the United States. Moreover, in India, in contrast to the West, household servants are typically male and construction labor is shared by both sexes. WOMEN's WORK, MEN's WoRk, supra note 2 , at 7.

15. C. EPSTEIN, supra note 11, at 155, 157. Likewise, as more women enter the medical profession in the United States, the qualities seen as essential to good doctoring are changing to encompass nurturing qualities associated with women. See, e.g., Klass, Are Women Better Doctors?, N.Y. Times, Apr. 10,1988, $\S 6$ (Magazine), at 32 (detailing ways in which qualities traditionally associated with women improve ability to treat patients). 
men. This "misstructuring" of jobs may take several forms. For example, many jobs historically held by men demand typically male physical characteristics because machinery used on these jobs has been adapted to the physique of its incumbents. ${ }^{16}$ Smaller women may not be able to use equipment designed for the male physique as efficiently or as safely as men and will therefore be deemed unsuitable for these jobs. ${ }^{17}$ Other job requirements reflect the family roles and work schedules that men have traditionally adopted. For example, many occupations in our society require frequent travel, night hours, or overtime work at little notice. ${ }^{18}$ Such schedules require the employee to subordinate family responsibilities to work requirements. ${ }^{19}$ Women, who still assume the greater burden of caring for children, other dependents, and the home, even while employed, ${ }^{20}$ cannot effectively compete against men for these jobs. ${ }^{21}$

16. Madden, The Persistence of Pay Differentials: The Economics of Discrimination, in 1 Women and Work: AN Annual Review 76, 78 (L. Larwood, A. Stromberg \& B. Gutek eds. 1985).

17. In the experience of American Telephone \& Telegraph, for example, women in outdoor jobs had higher accident rates than men while using equipment ordered when only men worked in the field. After the introduction of lighter-weight and more mobile equipment, however, women performed their jobs as safely as men. WOMEN's WORK, MEN's WORK, supra note 2, at 53; see also Boyd v. Ozark Air Lines, 419 F. Supp. 1061, 1064 (E.D. Mo. 1976) (airplane cockpits built with reference to man of average height may hinder performance of woman of average height), aff d, 568 F.2d 50, 54 (8th Cir. 1977); Hansen v. Department of Justice, Appeal No. 01821170, at 3 (E.E.O.C. Aug. 20, 1984) ("[T]he requirement that all trainees qualify on a K-frame gun adversely affected females because small handed trainees could not hold the training gun properly, and thus were unable to fire accurately.").

18. See Bourne \& Wikler, Commitment and the Cultural Mandate: Women in Medicine, in Women and Work 111 (R. Kahn-Hut, A. Kaplan Daniels \& R. Colvard eds. 1982); Frug, Securing Job Equality for Women: Labor Market Hostility to Working Mothers, 59 B.U.L. REv. 55, 55-59 (1979).

19. Rosabeth Moss Kanter includes wives as corporation members, recognizing that a male executive's productivity level requires his wife's support services, which allow him to give full attention to his job. R. KANter, MEn and Women of THE Corporation (1977); see also Rossi, Sex Equality: The Beginnings of Ideology, in Bexond Sex-Role Stereotypes 80, 86 (A. Kaplan \& J. Bean eds. 1976).

20. Data from a 1975-1976 survey of time use reveal that married women who work full-time devoted 24.6 hours of work per week to household tasks including child care compared to 12.1 hours for married men. O'Neill, Role Differentiation and the Gender Gap in Wage Rates, in 1 WoMEN AND WoRk: AN ANNUAL Review, supra note 16, at 50,57. A national study in 1977 found that husbands of employed women devote only 1.8 hours more in household care and 2.7 more hours in child care per week than husbands whose wives were full-time homemakers. J. PLECK, MEN's FAMILY Work: Three Perspectives and Some New Data (1979). These figures indicate that husbands perform at most half as much housework as their working wives. See Blau \& Ferber, Women in the Labor Market: The Last Twenty Years, in 1 WOMEN AND WoRk: AN ANNUAL Review, supra note 16, at 28.

21. See Frug, supra note 18, at 56-59. In order to accommodate child-rearing responsibilities, women are forced into less remunerative careers. See Nieva, Work and Family Linkages, in 1 Women AND Work: AN ANNUAL Review, supra note 16, at 162, 171 ; O'Neill, supra note 20, at 50, 62-64, 70-71. Approximately one in four women chooses part-time work, which pays significantly less than comparable full-time employment and usually offers little prospect for advancement. See id. at 57; Blau \& Ferber, Women in the Labor Market: The Last Twenty Years, in 1 WoMEN and Work: An AnNual Review, supra note 16, at 19,28. Others accept low-paying jobs in the home such as direct-mail or telephone sales. WOMEN's WORK, MEN's WoRK, supra note 2, at 74; see also Greenstein \& Greenstein, Labor Force Intentions of Mothers with Preschool Children: Constraining Effects of Lack of Childcare, in WOMEN AND WoRK: SELEcTed PAPERS 1985, supra note 12, at 149 (lack of satisfactory child care constrains labor force participation for many women). 
The link that is widely thought to exist between "male" characteristics and traditionally male jobs creates a vicious cycle for many women. Because these jobs are associated with the traits and lifestyles of men, employers fail to hire women who cannot or will not adopt "male" standards of behavior. Men therefore continue to dominate these positions, which, in turn, continue to be viewed as male and adapted to men. Women, meanwhile, remain trapped in the "pink collar" ghetto of the labor market.

\section{The Limits of Current Judicial Treatment: Title VII and Male-Biased Jobs}

Although title VII prohibits discrimination in employment on the basis of $\operatorname{sex}^{22}$ courts often fail fully to enforce this prohibition when malebiased standards are at issue. Courts either limit their inquiry to disparate treatment doctrine, which can neither identify nor eliminate these biases, or they apply disparate impact doctrine and defer to the employer's characterization of the job. In neither case do courts challenge the legitimacy of the job's requirements themselves.

\section{A. Disparate Treatment Analysis: Differences as Justification for Exclusion}

Courts have decided the majority of title VII sex discrimination claims by using disparate treatment doctrine ${ }^{23}$ which prohibits employment practices motivated by discriminatory intent. ${ }^{24}$ Yet, as this doctrine has been developed by courts, the prohibition on disparate treatment applies only to situations in which women are the same as men with respect to hiring criteria. Where women are different or perceived to be different from men on the basis of hiring criteria, disparate treatment doctrine's guarantee of "similar treatment for the similarly situated" lacks the power to identify and remedy male-biased requirements.

EEOC v. Sears, Roebuck $\mathcal{E}^{3} \mathrm{Co}^{25}$ illustrates the limitations of disparate treatment challenges to male-biased hiring standards. In that case, the Equal Employment Opportunity Commission (EEOC) argued that Sears, Roebuck Department Stores had discriminated on the basis of sex in hir-

Even when women choose to enter more demanding occupations, such as the professions, the difficulty of balancing work and family responsibilities channels a significant percentage of them into less demanding (and less prestigious) specialty areas. See, e.g., G. EPSTEIN, WOMEN IN LAw 328 (1983) (documenting sex segregation in legal specialties); Bourne \& Wikler, supra note 18, at 85-86 (same for medical specialties). Such job requirements typically disadvantage men as well as women by limiting the role men can play in parenting and in the home. See W. Farrell, The Liberated Man 131 (1975).

22. See supra note 1.

23. B. Babcock, A. Freedman, E. Norton \& S. Ross, Sex Discrimination and the Law: Causes and Remedies 330-31 (1975); see also Cooper, Title VII in the Academy: Barriers to Equality for Faculty Women, 16 U.C. Davis L. REv. 975, 987 (1983).

24. See supra note 9.

25. 628 F. Supp. 1264 (N.D. Ill. 1986), aff d, 839 F.2d 302 (7th Gir. 1988). 
ing for its highly paid commission sales positions. ${ }^{28}$ The EEOC demonstrated that although most of the applicants for sales positions were women, the department store selected far greater numbers of men to fill commission sales vacancies. ${ }^{27}$ In response to the EEOG's claim, Sears argued that a nondiscriminatory explanation for the disparities existed: Women were less interested in and less qualified for these positions than men. According to the defendant, although it sought women for commission sales positions, most women disliked the "dog-eat-dog" competition associated with these jobs, were uncomfortable with the evening hour demands which might conflict with family obligations, and were less familiar than men with the products sold on commission, including hardware, men's clothing, and automotive equipment. ${ }^{28}$

In analyzing the EEOC's claim of discrimination, the court applied disparate treatment analysis. ${ }^{29}$ As the court framed the issue under this analysis, the charge of discrimination turned on the adequacy of Sears' sup-

26. Between 1973 and 1980 , first year commission salespersons earned median wages of about twice those of all years of noncommission salespersons. Plaintiff's Pretrial Brief at 2-4, 27, 39-41, EEOC v. Sears, Roebuck \& Co., 628 F. Supp. (N.D. Ill. 1986) (No. 79-C-4373), affd, 839 F.2d 302 (7th Cir. 1988) [hereinafter Sears Brief], cited in Milkman, Women's History and the Sears Case, 12 FEMINIST STUD. 375, 381 (1986); see also EEOC v. Sears, Roebuck \& Co., 628 F. Supp. at 1289 (description of department store's compensation practices).

27. Most applicants did not specify whether they sought commission or noncommission sales, but were slated into the sales categories by those performing the hiring. Between 1973 and 1980, women made up $61 \%$ of full-time and $66 \%$ of part-time applicants for sales positions at Sears. Of those hired, however, women represented only $27 \%$ of full-time commission sales positions and only $35 \%$ of parttime commission sales positions. In contrast, Sears hired women for $73.5 \%$ of its noncommission sales positions. Sears Brief at 4, 28-30. The one exception to this disparity in hires occurred in Sears' midwestern territory, where women made up $52 \%$ of part-time commission hires during this period. Id.

28. 628 F. Supp. at 1305-15. According to the retailer, few qualified women could be found for commission sales positions and when these women were offered positions, they often turned them down. Id. at 1292-94, 1305-15. Rosalind Rosenberg, a historian specializing in women's history, provided the crux of Sears' case concerning women's "differences." She testified for Sears that the lack of women in commission sales jobs need not be the product of discrimination on Sears' part, but could instead be explained by the fact that women differ from men. Id. at 1308. According to Rosenberg, "[H]istorically, men and women have had different interests, goals, and aspirations regarding work. . . . It is naive to believe that the natural effect of these differences is evidence of discrimination by Sears." Winkler, Scholars' Conflict in Sears Sex-Bias Case Sets Off War in Women's History, Chron. of Higher Educ., Feb. 5, 1986, at 1, 8. This Note argues that there is no "natural effect" of women's differences from men that causes women to be disadvantaged; the disadvantaging is caused by biased standards and the social devaluation of qualities associated with women which are, indeed, discriminatory.

29. See supra note 9 (distinguishing between disparate treatment and disparate impact scrutiny). The court refused to apply disparate impact analysis because it held that Sears' subjective hiring criteria were not appropriately scrutinized under this doctrine, which should be used only for specific, objectively measurable hiring practices. $628 \mathrm{~F}$. Supp. at 1285 . This position, which was adopted by several courts, was overruled by the Supreme Court in Watson v. Fort Worth Bank \& Trust, 108 S. Ct. 2777 (1988); see infra note 50. The Sears court also refused to apply the disparate impact doctrine on the alternative ground that the plaintiffs had waived that cause of action by failing to raise the claim explicitly until the trial's closing arguments. 628 F. Supp. at 1279,1285 n.7.

The Sears court applied the form of disparate treatment scrutiny commonly used in government suits that is referred to as "pattern and practice." This type of action focuses on whether a pattern of discriminatory decisionmaking occurred rather than on whether individual employment decisions were motivated by discriminatory intent. International Bhd. of Teamsters v. United States, 431 U.S. 324, 360 n.46 (1977). 
posedly nondiscriminatory explanation-whether women were, in fact, different from men with respect to the stated hiring requirements. The court eventually found many women were genuinely less suited to and less interested in these jobs than men under these standards, and consequently held that Sears' hiring practices were nondiscriminatory. ${ }^{30}$ In reaching this decision, however, the focus of disparate treatment analysis on the issue of difference obscured the real problem in the Sears case: the stores' demand that commission salespersons display those characteristics largely possessed or perceived to be possessed by men.

As the court's description of Sears' hiring practices makes clear, Sears' hiring criteria for commission sales jobs were closely modeled on traits associated with men. The job description found by the judge to better apply to men demanded "aggressiveness or assertiveness, competitiveness, . . . persuasiveness, an outgoing . . . or extraverted personality, selfconfidence, personal dominance, [and] a strong desire to earn a substantial income ... ."31 It therefore almost perfectly captured the stereotypical American man. ${ }^{32}$ The tests used to screen applicants for these qualities also reflected a male bias. A questionnaire for the "vigor" Sears deemed necessary for the job sought affirmative answers to such questions as: "Do you have a low pitched voice?" "Do you swear often?" "Have you participated in wrestling?" "Have you played on a football team?"33 In addition, the qualities sought by interviewers were those found successful in past commission salespersons-almost all of whom were men. ${ }^{34}$ The commission sales job structure also favored men. Sears required that commission sales employees be available to work at night; as the court found, the requirement posed a particular hardship for women, who assume more responsibility for child care than men in our society. ${ }^{35}$ Moreover, as recognized by the court, most commission sales items, which included sporting

30. "The most egregious flaw [in the plaintiffs' disparate treatment case] is EEOC's failure to take into account the interests of applicants in commission sales and products sold on commission at Sears. EEOC turned a blind eye to reality in constructing its artificial, overinclusive "sales" pool, and assuming away important differences in interests and in qualifications." 628 F. Supp. at 1324, 1305-15.

31. Id. at 1290 .

32. For example, in a study in which men and women were asked to rate the degree to which particular attributes applied to men and women, subjects rated men as more ambitious, aggressive, independent, dominant, and self-confident than women. Miller, supra note 12; see also supra notes 11-12.

33. Sears Brief at 34. Sears allowed women to score lower on this test than men, however. Sears, $628 \mathrm{~F}$. Supp. at 1317 . In reaching its ruling, the court found that no credible evidence had been presented to determine that a woman's "vigor" score prevented her from being hired for commission sales. Id. at $1317-18$.

34. Id. at 1290 ("Many managers and personnel employees involved in the hiring process testified about the qualities they sought in commission sales people based on their own experience and the experience of their superiors."); Sears Brief at 4, 28-30.

35. 628 F. Supp. at 1308-09; see also supra note 20. 
goods, technical goods, automotive equipment, and men's clothing, fall into traditionally male areas of interest..$^{38}$

Nonetheless, disparate treatment analysis did not call these job requirements into question. ${ }^{37}$ Were Sears' job characterization and structure actually necessary for successful sales? Did salespersons have to be aggressive to sell merchandise successfully? Could Sears structure the commission sales department differently to decrease the competition that many women found disturbing, perhaps by pooling commissions? Must all employees necessarily be available for evening work? Why was men's clothing sold on commission when women's was not? Under current disparate treatment doctrine, which limits the guarantee of sexual equality to situations in which women are similarly situated to men with respect to hiring requirements, such questions about job structures are never answered because they are never asked..$^{\mathbf{3}}$

\section{B. Disparate Impact Analysis: Limitations on Griggs and Title VII's Equality Guarantee}

Disparate impact scrutiny, the other avenue of relief open to plaintiffs under title VII, can in theory reach entrenched biases like those in Sears. As established by the Supreme Court in Griggs v. Duke Power Co., ${ }^{39}$

36. 628 F. Supp. at $1306-08$.

37. For other cases demonstrating the limitations of disparate treatment doctrine, see, e.g., Field v. Bolger, 723 F.2d 1216, 1220 (6th Cir. 1984) (post office did not discriminate by refusing to adjust duties of pregnant employee who could not lift 70 pound loads required by job description because title VII does not require alteration of responsibilities of an employee "who, because of pregnancy, is unable to perform her full range of duties"); Zahorik v. Cornell Univ., 729 F.2d 85, 89-90 (2d Cir. 1984) (rejecting claim that denial of tenure to plaintiff violated disparate treatment prohibition despite evidence that she lacked support because she was "too 'feminine" as well as "unassuming, unaggressive, unassertive and not highly motivated for vigorous interpersonal competition").

38. Judicial examination of jobs from which women are explicitly excluded on the basis of sex marks the rare occasion when courts sometimes challenge existing job characterizations and structures under disparate treatment doctrine. Under title VII's statutory "bona fide occupational qualification" ("BFOQ") exception to the ban on disparate treatment of women, an employer may explicitly restrict jobs to members of one sex when sex is an occupational qualification "reasonably necessary to the normal operation of that particular business or enterprise." 42 U.S.C. $\$ 2000 \mathrm{e}-2(\mathrm{e})(1982)$. In ruling on whether women's explicit exclusion from jobs is permitted by the BFOQ exception, courts have sometimes looked beyond whether women could perform the job as it is currently characterized and structured to whether the employment standards that exclude women are in fact essential to job performance. See, e.g., Gunther v. Iowa State Men's Reformatory, 612 F.2d 1079 (8th Cir.) (court rejects defendants' claim that maleness is BFOQ for men's prison guard positions, holding that readjustments in job practices would result in acceptable accommodation between sex equality mandate and inmates' rights to privacy), cert. denied, 446 U.S. 966 (1980); see also B. SCHLEI \& P. GROsSMAN, Employment Discrimination LAw 341 (1983). But see Dothard v. Rawlinson, 433 U.S. 321, 334-36 (1977) (upholding exclusion of women from prison guard positions involving contact with prisoners on ground that women guards might get raped by sex offenders, without addressing adjustments that would accommodate women employees, such as housing all sex offenders in the same area). Courts more readily presume that explicit exclusion is illegitimate in such cases and interpret the BFOQ exception as "an extremely narrow exception to the general prohibition of discrimination on the basis of sex." Dothard v. Rawlinson, 433 U.S. at 334. Courts do not, however, approach challenges to positions from which women are implicitly excluded on the basis of male-biased job requirements with the same presumption.

39. 401 U.S. 424 (1971). 
facially neutral employment practices that have significant adverse effects on protected groups may violate title VII, whether or not these procedures are motivated by discriminatory intent. ${ }^{40}$ The legitimacy of a challenged practice is tested in three stages under disparate impact doctrine. ${ }^{41}$ In the first stage, the plaintiff bears the burden of establishing a prima facie case of discrimination by demonstrating that the challenged requirements have an adverse impact on a protected group. ${ }^{42}$ In the second stage, the burden of proof shifts to the defendant to rebut the prima facie case by showing that the practice is necessary to the business. ${ }^{43}$ Finally, in the third stage, a plaintiff may still succeed despite the employer's showing of business necessity if she demonstrates the existence of alternative practices that have a less discriminatory impact. ${ }^{44}$

The Supreme Court's construction of disparate impact doctrine properly encompasses male-biased job practices in the doctrine's ban. As with other prohibited practices, male-biased job requirements are "fair in form, but discriminatory in operation." 45 Moreover, such practices function as "artificial, arbitrary, and unnecessary barriers to [women's] employment" ${ }^{\text {"6 }}$ which have "operated in the past to favor an identifiable group of

40. In enacting the 1972 amendments to title VII, Congress specifically approved of the Supreme Court's expansion of the concept of discrimination in Griggs. See H. R. REP. No. 238, 92d Cong., 1st Sess. 8 (1971), reprinted in 1972 U.S. Code ConG. \& AdmIN. News 2137, 2144. Legislative history for the amendments states that Congress no longer conceives of discrimination as "primarily a problem of malicious intent on the part of individuals" but instead as "general rules and procedures [that] operate to the disadvantage of minorities and women in systemic fashion." Id. at 2159.

41. The Supreme Court defined this tripartite order in Griggs, 401 U.S. at 431-32, and Albemarle Paper Co. v. Moody, 422 U.S. 405, 425 (1975). See generally B. SCHLEI \& P. GrossmaN, supra note 38, at 1287, 1324-31 (discussing order and allocation of proof in disparate impact cases).

42. A plurality of the Supreme Court recently suggested that establishment of a prima facie case requires more than simply demonstrating statistical disparities in the employer's work force when subjective hiring practices are at issue. Watson v. Fort Worth Bank \& Trust, $108 \mathrm{~S}$. Ct. 2777, 2788 (1988). The plurality would demand that the plaintiff identify the specific employment practice allegedly responsible for any observed disparities and offer statistical evidence sufficient to show that the challenged practice has caused the exclusion. Id. at 2788-90.

43. Four members of the Supreme Court stated in Watson that although the employer has the burden of production at this stage of disparate impact analysis, the plaintiff retains the ultimate burden of proving that the practice is discriminatory. Id.

44. Albemarle Paper Co. v. Moody, 422 U.S. at 425 . Most courts require the plaintiff to shoulder the burden of establishing suitable alternatives with a lesser adverse impact. See, e.g., Chrisner v. Complete Auto Transit, Inc., 645 F.2d 1251, 1260-63 (6th Cir. 1981); Kirby v. Colony Furniture Co., 613 F.2d 696, 703-04 (8th Cir. 1980); Blake v. Gity of Los Angeles, 595 F.2d 1367, 1383 (9th Cir. 1979), cert. denied, 446 U.S. 928 (1980); Crockett v. Green, 388 F. Supp. 912, 920 (E.D. Wis. 1975), affd, 534 F.2d 715 (7th Cir. 1976). Yet, the Uniform Guidelines on Selection Procedures, 29 C.F.R. $\$ 1607$ (3) (1987), and some lower courts would require the defendant to shoulder the burden as a part of showing the necessity of the selection criteria. See, e.g., Robinson v. Lorillard Corp., 444 F.2d 791, 798 (4th Cir.), cert. dismissed, 404 U.S. 1006 (1971). Although placing the responsibility on the employer where a job does not accommodate women would seem preferable because the employer properly should consider alternatives more inclusive of women whether litigation occurs or not, four members of the Supreme Court recently suggested in Watson that the burden of proof is appropriately placed on the plaintiff at this stage. $108 \mathrm{~S}$. Ct. at 2790 .

45. Griggs, 401 U.S. at 431.

46. Id. Although some perceive male-biased job requirements as natural, reasonable, or necessary for job performance, these conclusions cannot be justified without exploration of alternatives. It is precisely because so many individuals perceive a norm based on "male" qualities as inevitable that the inequality of women is so entrenched in societal institutions. Cf. MacKinnon, Feminism, Marxism, 
.. employees over other employees." 'freeze' the status quo of prior discriminatory employment practices"48 by providing only token grants of opportunity, contrary to the Supreme Court's admonitions in Griggs. ${ }^{48}$ To implement the equality of opportunity guaranteed specifically by Griggs and more generally by title VII, jobs must be more than open to women in name alone-they must be accommodated to women as well as to men.

Courts, however, have typically failed to fulfill the promise of Griggs in their evaluation of male-biased job requirements. ${ }^{50}$ Rather than giving the careful scrutiny to these requirements that disparate impact analysis supposedly guarantees, courts have tended simply to assume that requirements that exclude women are inevitable features of the work place and thus uphold them with little scrutiny. The primary error in judicial use of disparate impact doctrine lies with the concept of "business necessity," which ensures that no employment practice with an adverse impact will be upheld under title VII unless the employer can show both that it is job related and that no less discriminatory substitute can be found. ${ }^{51}$ In inves-

Method, and the State: Toward Feminist Jurisprudence, 8 Signs 635, 638-39 (1983) ([M]ale dominance is perhaps the most pervasive and tenacious system of power in history . . . [I]t is metaphysically nearly perfect. Its point of view is the standard for point-of-viewlessness, its particularity the meaning of universality.").

47. Griggs, 401 U.S. at 430.

48. Id.

49. Id. at 431. Although all employers within an industry may not have intentionally discriminated in the past, current job descriptions could only assume "male" characteristics and life patterns to be necessary and normal because of women's historical exclusion from the work force. See supra note 6. Allowing stereotypes of jobs that developed during that period to continue to exclude women perpetuates this discrimination. Therefore, whether or not the employer intentionally discriminated against women at some prior time, she should bear the burden of dismantling job practices that retain these biases. In the Supreme Court's words, "[G]ood intent or absence of discriminatory intent does not redeem employment procedures or testing mechanisms that operate as 'built-in headwinds' for [protected] groups and are unrelated to measuring job capability." Griggs, 401 U.S. at 432.

50. See Cooper, supra note 23 , at 987 ("[W]hile disparate impact analysis has been a powerful tool in eliminating selection devices which are 'fair in form, but discriminatory in operation,' this theory has meant little to women.").

One barrier to the effective use of disparate impact doctrine has recently been removed. In the past, many courts limited the scope of disparate impact doctrine to objective hiring requirements such as literacy tests and high school diplomas. See, e.g., E.E.O.C. v. Federal Reserve Bank, 698 F.2d 633, 639 (4th Cir. 1983), rev'd on other grounds sub nom. Cooper v. Federal Reserve Bank, 467 U.S. 867 (1984); Pouncy v. Prudential Ins. Co., 668 F.2d 795, 799-801 (5th Gir. 1982); EEOC v. Sears, Roebuck \& Co., 628 F. Supp. 1264, 1281-84 (N.D. Ill. 1986), affd, 839 F.2d 302 (7th Cir. 1988). They therefore shielded from scrutiny the many non-objective hiring practices that denied women jobs, including such practices as interviewer assessments of candidates. However, the Supreme Court's recent decision in Watson v. Fort Worth Bank \& Trust, 108 S. Ct. 2777 (1988), definitively states that non-objective hiring practices are appropriately evaluated under disparate impact doctrine.

51. The open-ended nature of the business necessity defense has generated considerable literature concerning its appropriate scope. See, e.g., Brodin, Costs, Profits, and Equal Employment Opportunity, 62 Notre DAME L. REv. 318 (1987) (business necessity defense appropriate only when employee cannot perform job, not when employer would incur costs to adapt workplace to employee needs); Comment, The Business Necessity Defense to Disparate-Impact Liability Under Title VII, 46 U. CHI. L. REv. 911 (1979) (business necessity defense should protect almost all profit-maximizing practices); Notc, Business Necessity Under Title VII of the Civil Rights Act of 1964: A NoAlternative Approach, 84 YALE L.J. 98 (1974) (business necessity defense appropriate where practice serves some legitimate business purpose and has no less discriminatory alternatives). 
tigating the necessity of employment practices that exclude women, however, courts typically seek to determine only that selection practices effectively screen in an unbiased manner for the qualities and structures deemed necessary for the job by the employer. ${ }^{.2}$ They fail to recognize that the employer's conceptions of necessary job qualities and job structures may themselves contain entrenched discriminatory biases. ${ }^{63}$ In addition, courts consider in-depth scrutiny of a job's characterization and structure to be an inappropriate invasion of the province of the employer. ${ }^{54}$

Levin v. Delta Air Lines ${ }^{55}$ illustrates courts' "hands off" approach to existing job characterizations and structures. In that case, the Fifth Circuit found that the employer airline did not discriminate against pregnant flight attendants by compelling them to stop work during the full term of their pregnancy rather than reassigning them to available ground duties. ${ }^{56}$ According to the court, once the employer demonstrated the jobrelatedness of a practice, the practice would be considered nondiscriminatory unless an alternative practice accorded amenably "with the em-

52. For example, courts frequently strike down height and weight restrictions that are used to screen applicants for the job but which have little relevance to accepted notions of actual job performance. See, e.g., Dothard v. Rawlinson, 433 U.S. 321 (1977) (invalidating height and weight requirements for prison guards); United States v. North Carolina, 512 F. Supp. 968 (E.D.N.C. 1981) (striking down height requirement for state highway patrol officers that excluded more than three-fourths of female applicants); Officers for Justice v. Civil Serv. Comm'n of San Francisco, 395 F. Supp. 378 (N.D. Cal. 1975) (same with regard to city police patrol officers), affd, 688 F.2d 615 (9th Cir. 1982).

53. In Zahorik v. Cornell University, 729 F.2d 85 (2d Gir. 1984), for example, the court denied the plaintiffs' claim that the university's tenure selection process was discriminatory under disparate impact doctrine, despite the fact that $65 \%$ of men and only $42 \%$ of women received tenure. The court upheld the university's selection criteria on the ground that the criteria were "obviously" relevant to employment in tenured professorships. Id. at 96. Even the fact that the decisionmaking process was decentralized and it was therefore impossible to discern how fairly the criteria were applied was of no moment to the court, because the process was "based on generations of almost universal tradition." Id. at 86.

Similarly, in Boyd v. Ozark Air Lines, 419 F. Supp. 1061 (E.D. Mo. 1976), affd, 568 F.2d 50 (8th Cir. 1977), the court failed to challenge a height requirement for pilots despite its disproportionate impact on women, because the planes used by the airline were designed on the scale of the male physique. Refusing to question the purchase of the planes or to demand that, even prospectively, the airline purchase planes more accommodating to women's height, the court simply accepted the height restriction. According to the court, "The evidence showed that pilots must have free and unfettered use of all instruments within the cockpit and still have the ability to meet the design eye reference point. In view of the cockpit design, over which the defendant has little control, a height requirement must be established." Id. at 1064 .

54. See Contreras v. City of Los Angeles, 656 F.2d 1267, 1277 (9th Cir. 1981) (business necessity limitation demarcates an area of job characterization beyond which courts should not scrutinize unless practices are motivated by discriminatory intent), cert. denied, 455 U.S. 1021 (1982); deLaurier v. San Diego Unified School Dist., 588 F.2d 674, 677-81 (9th Gir. 1978) (upholding school district's policy of requiring pregnant teachers to stop work earlier despite medical evidence that most births occur within two weeks of the expected delivery date and women would experience no particular handicap in work before that period); see also Lynch v. Freeman, 817 F.2d 380, 391 (6th Gir. 1987) (Boggs, J., dissenting) (arguing that title VII does not permit scrutiny of underlying job conditions and structures, but only allows "the removal of barriers that are special to women so that they may then compete on the basis of their ability to do the actual job, given its [existing] conditions").

55. 730 F.2d 994 (5th Cir. 1984).

56. Id. 
ployer's customary practices." employer's customary practices might themselves be discriminatory in excluding women; by doing so, the court allowed the biased underlying job structure to justify the continued exclusion of women.

\section{Revising the Disparate Impact InQuiRy: Using Title VII to Eradicate Male-Biased Job Structures}

Job stereotypes and structures that unnecessarily exclude women violate title VII's guarantee of protection for women's employment opportunities. If the Griggs promise of equal opportunity is to have meaning for women, requirements that assume women must be exactly like men to perform jobs well must be rethought. ${ }^{88}$ This Note suggests a reformulation of disparate impact doctrine which will allow courts to better evaluate whether male-biased employment practices are truly related to optimal job performance. ${ }^{69}$ Because no a priori determination of the proper ratio of male

57. Id. at 1001; see also Harris v. Pan Am. World Airways, 649 F.2d 670 (9th Cir. 1980) (before passage of Pregnancy Discrimination Act, 42 U.S.C. $\S 2000 \mathrm{e}(\mathrm{k})$ (1982), employer's policy of requiring pregnant stewardesses to stop work within twenty-four hours of awareness of pregnancy upheld as a business necessity on customer safety grounds despite district court's findings that most women in early months of pregnancy can adequately perform the job and despite employer's failure to consider alternatives that might better accommodate women, such as assigning them ground work).

58. At least one legislative enactment already indicates that Congress recognizes that women should not be required to be the same as men in order to gain equality. The Pregnancy Discrimination Act (PDA), amending title VII, requires that courts find differential treatment disfavoring pregnant workers to be sex discrimination prohibited by title VII. 42 U.S.C. $\$ 2000 \mathrm{e}(\mathrm{k})(1982)$. Congress has thus recognized that forcing women to compete with men under male-biased standards is not the "natural" way to structure jobs, but a discriminatory impediment to women's full integration into the workforce. Senator Williams, for example, observed of the disparity in earnings between the sexes that:

These shocking statistics cannot be made better unless working women are provided effective protection against discrimination on the basis of their childbearing capacity. Testimony ... has shown that most policies and practices of discrimination against women in the workforce result from attitudes about pregnancy and the role of women who become pregnant which are inconsistent with the full participation of women in our economic system.

Because of their capacity to become pregnant, women have been viewed as marginal workers not deserving the full benefits of compensation and advancement granted to other workers. 123 CoNG. REC. 29,385 (1977) (statement of Sen. Williams), quoted in Note, Employment Equality Under the Pregnancy Discrimination Act of 1978, 94 YALE L.J. 929, 939 n.49 (1985). In one commentator's words, "Only when pregnancy is treated as a normal condition of employment will women secure employment equality. It is this vision that informs the PDA's passage." Id.

59. During the course of this Note's publication, changes in the federal judiciary have made it increasingly likely that courts will attempt to limit the use of disparate impact doctrine. The concurrence of four members of the Supreme Court in Watson v. Fort Worth Bank \& Trust, $108 \mathrm{~S}$. Ct. 2777 (1988), provides strong indication that the Court may move toward requiring a higher standard of proof that could effectively bar many of the claims that urgently need to be pressed under disparate impact doctrine. Should this occur, it may be more effective for plaintiffs to pursue claims challenging male-biased standards under disparate treatment doctrine. Although most courts have failed to properly approach the real problems with male-biased standards under this doctrine, see supra notes 23-38 and accompanying text, a few courts have moved beyond futile questions of similarity and difference using this test. See, e.g., Hopkins v. Price Waterhouse, 618 F. Supp. 1109 (D.D.C. 1985), aff'd in part, rev'd in part on other grounds, 825 F.2d 458 (D.C. Cir. 1987), cert. granted, 108 S. Ct. 1106 (1988); see also infra note 72 . To make a claim under disparate treatment doctrine, plaintiffs might argue that although the challenged male-biased structures were not intended to exclude women, the maintenance of a system that excludes women and that perpetuates outdated notions 
to female employees in an occupation is possible, and because conceptions of optimal job performance are currently so mired in male-biased assumptions that disentangling them will take time, this proposal aims to encourage courts and employers carefully to rethink male-biased assumptions rather than attempt to determine in advance in which cases courts should order remedies.

\section{A. Adverse Impact}

At the first stage of a disparate impact case, the standards of statistical proof currently used by courts to establish that a challenged requirement has an adverse impact on protected groups should suffice to identify malebiased employment practices. ${ }^{60}$ Courts should, however, carefully avoid using stereotyped notions of job performance to define the pool against which the adverse impact of the requirements is measured, as defining the pool in this way could make it unnecessarily male and thereby obscure the practice's adverse impact. ${ }^{81}$ Thus, the employer should be required to show the business necessity of controversial requirements used to limit the relevant pool. ${ }^{62}$

\section{B. The Business Necessity Defense}

At the second stage of disparate impact scrutiny, employers must establish the business necessity of the challenged requirements. When evaluat-

about the roles that women can proficiently assume constitutes "omissive and subtle" discrimination sufficient to constitute a disparate treatment violation. 618 F. Supp. at 1119.

For another proposal that a revitalized disparate impact doctrine be used to eliminate standards skewed against women, see Taub \& Williams, supra note 8.

60. See generally B. SchleI \& P. Grossman, supra note 38, at 1331-91 (describing methods of statistical proof).

61. See Bartholet, Application of Title VII to Jobs in High Places, 95 HaRv. L. Rev. 945, 970-73 (1982). For example, in Wheeler v. Armco Steel Corp., 471 F. Supp. 1050 (S.D. Tex. 1979), the court confined the relevant labor pool for a non-entry level position to employees within the company rather than the metropolitan area labor market. In doing so, the court allowed any discriminatory criteria used to select entry-level employees to be passed along to the challenged position. See also Copus, The Numbers Game is the Only Game in Town (Comment), 20 How. L.J. 374, 382-90 (1977) ("The most common errors in statistical proofs which incorporate the effects of institutional discrimination involve determining the race/sex/ethnic composition of the relevant labor pool.").

Where the job involves an entry level position for which most persons could easily become qualified, defining the pool as the working age population will ensure that the pool accurately reflects potential jobholders. Examining the effects of a requirement on a broader pool rather than on the actual applicant pool will provide a more accurate indication of disparate impact because fewer women may apply where sex-biased requirements make the job less attractive to women. See Dothard v. Rawlinson, 433 U.S. 321, 330 (1977) (showing of disproportionate impact need not be based on actual applicant pool because "qualified people might be discouraged from applying because of a self-recognized inability to meet the very standards challenged as being discriminatory"); WOMEN's WoRk, MEN's Work, supra note 2, at 79-80 (women's perceptions of lack of opportunity profoundly affect their occupational choices).

62. See, e.g., Grant v. Bethlehem Steel Corp., 635 F.2d 1007 (2d Cir. 1980) (requiring showing of business necessity for work experience demanded of applicants before using this requirement to narrow the pool), cert. denied, 452 U.S. 940, 1017-20 (1981); see also Watkins v. Scott Paper Co., 530 F.2d 1159, 1192-94 (5th Cir.) (similar), cert. denied, 429 U.S. 861 (1976). Clearly uncontroversial requirements that the plaintiff does not wish to contest would not require such a demonstration. 
ing requirements for a male bias, courts should use a two-part test to ensure that they do not accept stereotyped assumptions regarding job performance as business necessities. They should first ask whether the challenged requirement is essential to the core function of the job. If the answer is affirmative, courts should then consider whether the selection process screens for that requirement in an unbiased manner.

The core function test would require courts to look beyond stereotyped notions of how the job should be performed to the basic function of the job itself. This test would enable courts to determine whether the requirement and the job itself are actually closely linked. ${ }^{63}$ Judges have used this concept to eliminate job stereotypes when employers have sought explicitly to bar one sex from particular jobs on the basis of title VII's exception to the ban on disparate treatment for jobs in which sex is a bona fide occupational qualification. ${ }^{64}$ For example, in Diaz v. Pan American World Airways, ${ }^{68}$ a disparate treatment case, the court struck down an airline's bar on hiring male stewards, despite the airline's claim that women were needed to give passengers more "courteous personalized service." cording to the court, whether women were better able to do so or not was not the issue, for this ability was "tangential to the essence of the business involved," the safe transport of passengers. ${ }^{87}$

Where a clear-cut determination of the job's core function is difficult, as might be the case, for example, in many professional positions, judicial scrutiny should focus on the extent of the employer's effort to rethink the necessity of the job's requirements in light of their discriminatory impact. ${ }^{88}$ For these purposes, the employer, at the very least, should have

63. The core function test presumes that it will be possible to determine crucial tasks, at least for a large number of jobs. For instance, the most crucial aspect of a pilot's job will be to fly an airplane safely, and the most crucial aspect of a mechanic's job will be to fix a car. Cf. B. ScHLeI \& $P$. Grossman, supra note 38, at 1329 (suggesting that standards used to establish business necessity should vary with nature of requirements challenged as discriminatory).

64. See id. at 341 (courts inquire whether challenged functions are essential to the job). See generally supra note 38 .

65. 442 F.2d 385 (5th Cir.), cert. denied, 404 U.S. 950 (1971).

66. Id. at 387 .

67. Id. at 388; see also Blake v. City of Los Angeles, 595 F.2d 1367 (9th Cir. 1979), cert. denied, 446 U.S. 928 (1980). In Blake, the court rejected the defendants' argument that police officer positions demanded minimum height limitations because tall officers could better control suspects and observe field situations. The court observed that height and weight requirements could run the other way: "Shorter officers may have certain advantages in observing field situations (e.g., the ability to look under objects, the ability to squeeze through narrow passageways) that tall officers lack." Id. at 1379 n.7.

68. Emphasis on the employer's effort to rethink the job accords with current judicial application of disparate impact doctrine to subjective hiring practices. Most cases finding violations involving subjective criteria have involved poorly conceived subjective systems that failed to control evaluator biases in assessing either the job or the employee. See, e.g., Rogers v. International Paper Co., 510 F.2d 1340, 1345-46 (8th Cir.) (employers must guard against biases in hiring process), vacated and remanded on other grounds, 423 U.S. 809 (1975); Greenspan v. Automobile Club, 495 F. Supp. 1021, 1033-35 (E.D. Mich. 1980) (defendant faulted for failing to develop process of job evaluation and employee selection that assures candidates meet actual job demands); Wade v. Mississippi Soop. Extension Serv., 372 F. Supp. 126, 142 (N.D. Miss. 1974) (same), affd in relevant part, 528 F.2d 
analyzed the job to determine the qualities essential to effective job performance. Such an analysis should persuasively demonstrate that the requirements are truly necessary to perform the job well, rather than are simply a description of the traits needed to perform the job in the same way as the job is currently performed. ${ }^{69}$

In addition to demonstrating that the traits that employers require are essential to the core function of the job, employers should demonstrate that selection procedures which screen for these traits are free of stereotypes. ${ }^{70}$ At this stage, procedures commonly used by courts to assess disparate impact claims can be employed to determine whether the screening procedure is biased. ${ }^{71}$ When the screening process involves the subjective assessment of applicants-as, for example, when a plaintiff contends that an interviewer sought to determine vigor in a way reflecting masculine stereotypes-determining bias becomes somewhat more difficult. In such cases, courts should require that subjective hiring systems set out stan-

508, 518 (5th Cir. 1976). A well designed rating system helps employers avoid liability in those situations. B. SCHLEI \& P. Grossman, supra note 38, at 201-02; see also Bartholet, supra note 61, at 990-91 (most employers lose disparate impact cases because of inability to answer fundamental questions about job-relatedness of requirements).

69. See Bartholet, supra note 61, at 1010 ("The job description approach (in contrast to assessment of actual job requirements] is likely to lead to the creation of 'new' selection systems that perpetuate the racial exclusion characterizing the old system."). Bartholet's discussion reveals the problem with the approach used in cases such as Contreras v. City of Los Angeles, 656 F.2d 1267 (9th Cir. 1981), cert. denied, 455 U.S. 1021 (1982), in which the court accepted a job description produced by having incumbents determine the qualities they believed essential to job performance. Id. at 1281-82.

Courts should require job analyses to be recent to avoid exclusion of women that is not justified on the basis of current circumstances. Under this standard, Sears' job description, developed in 1953, Milkman, supra note 26 , at 382 , would have been presumptively invalid. Similarly, employers must rethink height, weight, and strength requirements in light of new technology. In addition, industrywide use of particular requirements would not be a valid defense to a discrimination claim because male-biased job requirements often pervade an entire industry.

70. See, e.g., Dothard v. Rawlinson, 433 U.S. 321, 331-32 (1977) (striking down height and weight requirements that excluded women as biased way to select for strength, the required characteristic); see also Leisner v. New York Tel. Co., 358 F. Supp. 359, 365 (S.D.N.Y. 1973) (employer's willingness to deem military service, but not teaching school, to be evidence of leadership, found discriminatory); B. Schlei \& P. Grossman, supra note 38, at 202 (employer must screen for qualities in ways that consider both men's and women's experiences).

71. Employers may use principles developed by testing experts to "validate" these requirements by establishing that screening procedures effectively predict on-the-job performance. See Albemarle Paper Co. v. Moody, 422 U.S. 405 (1975); Uniform Guidelines on Employee Selection Procedures, 29 C.F.R. $\$ \S 1596,1607.5,1607.16(D)-(F)(1983)$. For an overview of validation techniques, see generally B. Schlei \& P. Grossman, supra note 38, at 102-55.

The trial court's opinion in Berkman v. City of New York, 536 F. Supp. 177 (E.D.N.Y. 1982), aff'd in part, rev'd in part, 812 F.2d 52 (2d Gir. 1987), provides an excellent example of this sort of inquiry. In that case, the City of New York introduced a timed mile run to measure the endurance of firefighter candidates. Relying on validation techniques, the court struck down the requirement as measuring strength and speed rather than endurance:

The test was designed to measure stamina or aerobic capacity-something it will do only for runners taught to pace themselves in running. In the absence of pacing, the test measures not stamina or aerobic capacity - that is, the ability of the body to generate energy from oxygen uptake-but anaerobic capacity - the ability of the body to generate energy from itself, something also measured by [defendants'] strength tests. . . . "Firefighting is," as one witness testified, "not a sprint event."

Id. at 204. 
dards of evaluation with enough specificity to limit the potential for discrimination. ${ }^{22}$

\section{Available Alternatives}

If an employer proves that the contested practices are a business necessity, at the third stage of the disparate impact case the court must still determine whether the employer could use alternative employment devices of comparable business utility that have a less discriminatory impact. ${ }^{73}$ At this stage, employers should be required to show that they have considered alternative means of performing the job and that these alternatives have proven unsatisfactory. ${ }^{74}$ For example, where positions exclude women on the basis of demands for extensive overtime, employers should be required to show they have explored alternative ways that the jobs could be structured that would better accommodate family responsibilities. Employers might therefore be obligated to explore such options as job sharing, schedules with flexible hours, and systems in which employees receive compensatory time off if they have to work overtime. Plaintiffs should have an opportunity to rebut the employers' claims with their own studies or with evidence that other employers have found it feasible to structure similar jobs in ways more inclusive of women. ${ }^{75}$

Employers should also be required to show that job requirements do not disadvantage women by undervaluing their strengths. For instance,

72. Hopkins v. Price Waterhouse, 618 F. Supp. 1109 (D.D.C. 1985), affd in part, rev'd in part on other grounds, 825 F.2d 458 (D.C. Cir. 1987), cert. granted, 108 S. Ct. 1106 (1988), a disparate treatment case, illustrates the type of scrutiny which courts should use. Hopkins, in counterpoint to the issue presented in this Note, involved a woman who was penalized for not being perceived as appropriately "feminine" by her employers at an accountng firm. The district court held that the defendants had discriminated by failing to root out evident sexism from an evaluation system that allowed considerable unconscious sexual stereotyping. 618 F. Supp. at 1118-19; see also Albemarle Paper Co. v. Moody, 422 U.S. at 432-33 (criticizing performance rating system that allowed evaluator biases to enter into ratings); Bauer v. Bailar, 647 F.2d 1037, 1043 (10th Cir. 1981) ("Subjective hiring and promotion decisions, particularly where made in the absence of specific standards and guidelines[,] may not go unexplained if there is a significantly disproportionate non-selection of members of a group over an extended period."); Rowe v. General Motors Corp., 457 F.2d 348, 358-59 (5th Cir. 1972) (under disparate treatment doctrine, promotion procedures involving subjective evaluations that fail to guard against biases are discriminatory).

73. See supra note 44 .

74. The burden may also be placed on the plaintiff to show that alternative practices exist. See supra note 44.

75. Courts have sometimes, albeit infrequently, ordered changes in ostensibly neutral working conditions to accommodate women. See, e.g., Lynch v. Freeman, 817 F.2d 380, 384-85 (6th Cir. 1987) (providing only unsanitary toilet facilities for employee use violates disparate impact doctrine where women are at higher risk of infection from unsanitary conditions than men); $c f$. De La Cruz v. Tormey, 582 F.2d 45 (9th Cir. 1978) (refusing to grant defendant's motion for summary judgment where plaintiff claimed defendant's refusal to allow child care facilities at community college violated the equal protection clause and title IX), cert. denied, 441 U.S. 965 (1979). Courts also occasionally have ordered the restructuring of jobs inappropriate for pregnant women: See, e.g., Hayes v. Shelby Memorial Hosp., 726 F.2d 1543, 1554 (11th Cir. 1984) (ordering hospital to investigate alternatives that would allow pregnant employees in radiology department to continue to work without danger to fetus). Courts have more often ordered changes in job conditions when striking down explicit bars to women's employment. See supra note 38 and accompanying text. 
employers should demonstrate that job descriptions that demand only physical characteristics commonly associated with men, such as strength and speed, do not ignore the importance of attributes associated with women, such as flexibility, balance, endurance, and agility. ${ }^{78}$ If the latter characteristics are found appropriate for the job's performance, courts should require their incorporation into the job description. A court might thus have insisted that Sears justify its commission sales description's omission of qualities traditionally associated with women that might improve commission sales prowess, such as the ability to listen well to the needs of customers.

\section{Cost}

Whether a practice is a business necessity and whether alternative practices are feasible will frequently turn on the issue of cost. Most jobs that require significant overtime, for example, could have their work divided among more employees-it might simply cost the employer more to do so. Similarly, equipment designed for the male physique could be replaced with equipment better suited to women-for a price.

When evaluating claims based on costs, courts should not simply assume that alternative practices will necessarily be more costly than current practices. Recharacterizing and restructuring male-biased jobs will in many instances lower, rather than raise, costs. Demands for characteristics and life patterns not truly necessary for a job narrows the applicant pool by eliminating suitable candidates. Similarly, failure to require "non-masculine" traits that are useful for the job precludes selection of optimal candidates.

If a case arises in which values of cost and equality do compete, where a court draws the line between the two will necessarily depend upon the facts of that specific case. ${ }^{77}$ However, claims of cost should never be treated as determinative; title VII does not allow discrimination merely because it is profitable. ${ }^{88}$ Thus, courts should impose a strict standard of

76. See Berkman v. City of New York, 626 F. Supp. 591, 599 (E.D.N.Y. 1985), affd in part, rev'd in part, 812 F.2d 52 (2d Cir.) (criticizing firefighting test that deemphasizes endurance in favor of strength and speed as "invidiously discriminat[ing] against women"), cert. denied, $108 \mathrm{~S}$. Ct. 146 (1987); Colker, Rank-Order Physical Abilities Selection Devices for Traditionally Male Occupations as Gender-Based Employment Discrimination, 19 U.C. DAvis L. REv. 761, 778 (1986).

77. Title VII does not clarify how costs should be balanced against the value of eradicating discrimination. Congressional intent to eliminate intentional discrimination, even if to do so proves uneconomical, is clear. Frug, supra note 18, at 73 . Yet the increasing recognition by Congress and the courts that discrimination includes far more than job practices that are motivated by deliberate ill-will may lead to imposition of far greater costs, in tension with title VII's respect for business efficiency and productivity. Id.; see House Judiciary Comm. Rep., Additional Views of Reps. McCullock, Lindsay, Cahill, Shriver, MacGregor, Mathias, and Bromwell, H. R. Rep. No. 914, 88 Th CoNG., 1st SEss. 2, 29 (1963); Note, supra note 51, at 104.

78. See City of Los Angeles, Dep't of Water \& Power v. Manhart, 435 U.S. 702, 717 (1978). ("[N]either Congress nor the courts have recognized ... such a [cost justification] defense under title VII."); Robinson v. Lorillard Corp., 444 F.2d 791, 799 n.8 (4th Cir.) (in "determining the existence 
necessity on employers who present cost claims by, for example, requiring them to show substantial harm to the business. ${ }^{79}$ This relatively high standard for business necessity recognizes that cost to an employer should not justify forcing women to subsidize a discriminatory business by working at lower-paying jobs elsewhere, or not at all. ${ }^{80}$

Insofar as courts read cost limitations into title VII, they restrict the practices that courts can find remediable under the statute. They do not, however, diminish progress toward the primary objective of this Note: rethinking job requirements that are biased in favor of men. Whether judges eventually outlaw a large number of existing male-biased practices may ultimately be of less importance than their insistence that employers and other members of the labor market recognize that such practices are often unnecessary for job performance.

\section{ConClusion}

This Note calls for judicial recognition that job standards that exclude women do not do so because women are inherently unfit to perform these jobs. Rather, such job standards reflect biased assumptions about the way that work must be performed that are derived from the social valuation of the relative worth of men and women. Courts must use title VII to challenge these biased notions regarding optimal job performance if women are truly to receive the equality of opportunity in employment promised by the statute. It is time to recognize that jobs modeled on the male image are neither necessary nor appropriate in a society composed of both women and men, and to adapt such jobs to both sexes.

of business necessity, dollar cost alone is not determinative"), cert. dismissed, 404 U.S. 1006 (1971); Wilson v. Southwest Airlines Co., 517 F.Supp. 292, 304 (N.D. Tex. 1981) ("Ioss of competitive advantage . . . does not establish business necessity" insofar as it would limit title VII coverage to "financially successful enterprises"). See generally Brodin, supra note 51 (only legitimate reason to discriminate is inability to perform job, not expense of accommodating different traits of workers).

79. In addition to cost, safety factors must also be considered under disparate impact doctrine. Courts must weigh the safety factors associated with alternative practices and determine whether they have sufficient weight to override their discriminatory impact. Thus, a court might weigh heavily a hospital's claim that an alternative scheduling practice is impractical because it interferes with the doctor-patient relationship necessary for safe medical care. On the other hand, a court might weight a law firm's claim that alternative scheduling would disrupt the lawyer-client relationship less heavily.

80. Where the employer successfully demonstrates business necessity, courts probably cannot order changes that would benefit women without a more stringent statutory mandate than title VII provides. See Frug, supra note 18, at 73. Given the prevalence of job structures that exclude women in our society and the disadvantaged position in which such job structures place women, such statutory change is badly needed. $C f$. id. at $95-102$ (suggesting legislative solutions to problems of working mothers). Nevertheless, should a judge find that wholesale reorganization of a particular job is not justified in view of the substantial costs required, she should, when appropriate, order less costly changes in order to increase the availability of the job to women. 
